\title{
MORPHOLOGICAL CHARACTERIZATION OF VARIETIES OF Chenopodium quinoa CULTIVATED IN THE DEPARTMENT OF BOYACÁ, COLOMBIA
}

\section{CARACTERIZACIÓN MORFOLÓGICA DE VARIEDADES DE Chenopodium quinoa CULTIVADAS EN EL DEPARTAMENTO DE BOYACÁ, COLOMBIA}

\author{
Harvey Infante R. ${ }^{1}$, Sofía Albesiano ${ }^{2}$, Leopoldo Arrieta V. ${ }^{3}$, Nubia Gómez V. ${ }^{4}$
}

${ }^{1}$ Biólogo, Grupo de Estudios en Genética y Biología Molecular GEBIMOL, Facultad de Ciencias Básicas. Universidad Pedagógica y Tecnológica de Colombia, e-mail: harvey.infante@uptc.edu.co, (1Dhttps://orcid.org/0000-0002-9516-1450; ${ }^{2}$ Ph.D, Docente Investigador, Grupo GEBIMOL, Facultad de Ciencias Básicas. Universidad Pedagógica y Tecnológica de Colombia, e-mail: adriana.albesiano@uptc.edu.co, (Dhttps://orcid.org/0000-0002-8672-6018; ${ }^{3}$ M.Sc. Docente Investigador, Grupo GEBIMOL, Facultad de Ciencias Básicas. Universidad Pedagógica y Tecnológica de Colombia, e-mail: leopoldo.arrieta@uptc. edu.co, (Dhttps://orcid.org/0000-0003-0050-7314; ${ }^{4} \mathrm{Ph} . D$. Docente Investigador, Grupo de Estadística -GAMMA-, Facultad de Ciencias Básicas. Universidad Pedagógica y Tecnológica de Colombia, e-mail: nubia.gomez@uptc.edu.co, (iDhttps://orcid. org/0000-0001-7745-1721

Rev. U.D.C.A Act. \& Div. Cient. 21(2):329-339, Julio-Diciembre, 2018 https://doi.org/10.31910/rudca.v21.n2.2018.977

Open access article published by Revista U.D.C.A Actualidad \& Divulgación Científica under a Creative Commons CC BY-NC 4.0 International License

\section{ABSTRACT}

In the department of Boyacá, seeds of Chenopodium quinoa Willd. are planted, which correspond to a mixture of varieties, producing different grain sizes and saponin concentrations, affecting the quality and yield of the derived products, and therefore their commercialization, whenever the buyer requires it for a certain purpose, sweet varieties for bakeries or with high contents of saponin for the detergent industry. The objective was to compare the morphological characters, to identify the six varieties, according to the constant and conspicuous characteristics, as well as physiological parameters in the reproductive and vegetative stages. Observations were made in the different stages of development; in seeds, germination tests were made, the diameter and weight were measured; In the seedling stage, the total height, hypocotyl length, cotyledon lamina length and changes in red pigmentation were determined, qualitatively evaluated by direct observation. In adult plants, reproductive and vegetative characters were reviewed. A taxonomic key was proposed for the identification of the varieties. Blanca Real recorded the highest germination percentage (98\%). Amarilla Marangani presented the seeds with the greatest weight and diameter and the longest cotyledons. The height of the Black and Piartal seedlings was below the other varieties. Blanca de Jericó,
Blanca Real and Piartal presented weak reddish colorations in the hypocotyl and cotyledons. The identification of each variety will result in better products for growers, marketers, and processors.

Keywords: taxonomy key, seed germination, morphology, Quinoa, varieties.

\section{RESUMEN}

En el departamento de Boyacá, se siembran semillas de Chenopodium quinoa Willd., las cuales, corresponden a una mezcla de variedades, produciendo diferentes concentraciones de saponina y de tamaños de grano, afectando la calidad y el rendimiento de los productos derivados y, por tanto, su comercialización, toda vez que el comprador lo requiere para un determinado fin, como variedades dulces, para las panaderías o, con altos contenidos de saponina, para la industria de detergentes. El objetivo fue comparar los caracteres morfológicos, para identificar las seis variedades, de acuerdo con las características constantes y conspicuas, además de parámetros fisiológicos en etapa reproductiva y vegetativa. Se realizaron observaciones en las diferentes etapas del desarrollo; en semillas, se hicieron pruebas de germinación, se midió el diámetro y el peso; en el estadio de plántula, se de- 
terminó la altura total, longitud del hipocótilo, largo de la lámina de los cotiledones y cambios en la pigmentación rojiza, evaluada cualitativamente por observación directa. En plantas adultas, se revisaron caracteres reproductivos y vegetativos. Se propuso una clave taxonómica, para la identificación de las variedades. Blanca Real registró el porcentaje de germinación más alto (98\%). Amarilla Maranganí presentó las semillas con el mayor peso y diámetro y los cotiledones más largos. La altura de las plántulas Negra y Piartal estuvo por debajo de las otras variedades. Blanca de Jericó, Blanca Real y Piartal presentaron coloraciones rojizas débiles en el hipocótilo y en los cotiledones. La identificación de cada variedad redundará en mejores productos para los cultivadores, comercializadores y procesadores.

Palabras clave: clave taxonómica, germinación de semillas, morfología, quinua, variedades.

\section{INTRODUCTION}

Quinoa, Chenopodium quinoa, is native to the Andes, and is distributed from southern Chile and Argentina to Colombia (Bazile et al. 2014), between sea level and $4.000 \mathrm{~m}$ altitude (Veloza et al. 2016). It was introduced in North America, Africa, Asia and Europe (Bazile et al. 2014; Morillo et al. 2017). Cultivated in a traditional way since the Inca period (Delgado et al. 2009), standing out as a staple food in the diet of some peoples of South America (Torres et al. 2000). In Colombia, it is grown in the departments of Boyacá, Cauca, Cundinamarca and Nariño (Dueñas, 2014). In Boyacá, crops between 2.538 and $3.031 \mathrm{~m}$ of altitude are reported in the provinces of Centro, Tundama and Sugamuxi (Veloza et al. 2016), with an average production of 5.37 tons and an average yield of 1.96 tons per hectare (Ministerio de Agricultura y Desarrrollo Rural, 2005; Departamento Administrativo de Planeación de Boyacá, 2016).

It is an expanding crop, due to the nutritional value of its fruit, high protein content, since it has all the amino acids, trace elements and significant amounts of vitamins $\mathrm{B}, \mathrm{C}$ and $\mathrm{E}$, as well as important minerals $\mathrm{Ca}, \mathrm{K}, \mathrm{Fe}, \mathrm{Mg}, \mathrm{Mn}, \mathrm{P}$ and isoflavones that can contribute to their antioxidant properties (Montoya et al. 2005; Delgado et al. 2009; Vega et al. 2010; González et al. 2011; González et al. 2012; Prado et al. 2014; González et al. 2015; Morillo et al. 2017; Sayago et al. 2017; Reguera et al. 2018). Also, due to its capacity to adapt to different agroecological zones and its resistance to adverse abiotic factors, frosts, low levels of organic matter, salinity and drought (Veloza et al. 2016). Conditions that occur in the provinces of Boyacá where it is grown. In the last decade it has had an important recognition by governmental organizations at a national and international level, promoting actions aimed at replanting it and shaping its productive chain (Betancourth et al. 2007; Dueñas, 2014).
It is a small-scale crop in our country, where the indiscriminate mix of varieties, together with a low level of technology, reduce its quality and profitability (Veloza et al. 2016). Due to the lack of plantations of a single variety, technological problems arise, such as the heterogeneity in the morphological characteristics and the maturation times of the individuals (Delatorre et al. 2013; Dueñas, 2014).

There is information on the morpho-agronomic characterization of the Ch quinoa varieties cultivated in the savannah of Bogotá and in Nariño, where the height of the individuals, length of the inflorescence, seed weight, among others were evaluated (Torres et al. 2000; Delgado et al. 2009; Veloza et al. 2016); however, in Boyacá there has not been a study where the morphological characteristics of the cultivated varieties are described. It is necessary to carry out studies that allow a correct selection of the material, with a view to improving the production process. Therefore, the objective was to recognize the reproductive characteristics, vegetative and some physiological parameters in three stages of development, seed, seedlings and adult plants, which allow identifying the six varieties, Amarilla Maranganí (AM), Blanca de Jericó (BJ), Blanca Real (BR), Negra (NE), Piartal (PI) and Tunkahuán $(\mathrm{TH})$; known by the peasants of the region and who have not been given a morphological characterization.

\section{MATERIALS AND METHODS}

The characterization was carried out in three stages of the biological cycle of Ch. quinoa in the Laboratory of Genetics and Molecular Biology of the Pedagogical and Technological University of Tunja.

Seeds: The varieties, AM, BJ, BR, NE, PI, and TH, obtained from the Germplasm Laboratory of the Gobernación de Boyacá-Colombia, were analyzed, to which the following measurements were taken: Diameter: to 10 seeds by varying the diameter was measured with a micrometric screw of 0.0 $25 \mathrm{~mm}$. Weight: a group of a thousand seeds per variety was registered weight, with the scale Lexus, Model Mix-A. Germination tests: 50 seeds were taken per variety and placed separately in Petri dishes on filter paper moistened with distilled water. After 24 hours, we counted the number of seeds that showed rupture of the testa and the emergence of the radicle.

Seedlings: Follow-up to the development of seedlings: 48 seeds of the six varieties were planted, in germination trays and with peat as a substrate, divided into three replicas. This test was carried out 4 to 5 days after the emergence of the substrate, in Tunja, at an altitude of $2810 \mathrm{~m}$. A total and long height of the lamina of the cotyledons: measurements made on days $5,6,14,17,28,35$ and 49 of the development. The height was measured from the substrate to the apex of 
the seedling. Reddish pigmentation: Product of betacyanins (González et al. 2012; Masaaki, 2014; González et al. 2015; Sayago et al. 2017), was evaluated qualitatively according to the weak, medium and strong states, determined by direct observation.

Adult plants: Four varieties were considered, AM, BJ, PI, and $\mathrm{TH}$, of crops established in the following locations, BJ and $\mathrm{TH}$ in the municipality of Siachoque-Province Center, altitude $2.760 \mathrm{~m}$; AM in Tunja-Province Center, $2.810 \mathrm{~m}$ and PI in Tibasosa-Province Sugamuxi, $2.538 \mathrm{~m}$. Ten healthy plants were selected, free of diseases, pests and nutritional deficiencies. The following data were recorded: height of the plants; root: length of the primary and secondary roots; stem: color, diameter, presence of ribs and pigmented axils; leaves: color and shape of the petiole; width, length and number of teeth of the blade; panicle: shape and color (Font-Quer, 1979; Moreno, 1984).

Finally, the extended description of the species was made, based on the reproductive and vegetative characteristics of the varieties studied. Two comparative tables between the varieties were proposed and a taxonomic key, which included characters of the adult plants (Tables 3, 4).

Experimental design: For the size of the seeds, a completely randomized, balanced design was used, at 10 seeds per variety, with the variety being the main factor, and diameter the response variable. To monitor the development of seedlings, we worked with 48 seeds of the six varieties, in a factorial design, with blocking factor days of measurement. The main factor consisted of the variety and the answer variables were the height of the seedling and the length of the lamina of the cotyledons. The vegetative characteristics were analyzed with a completely randomized design, with a factor corresponding to the variety. The response variables, length of the petioles, length and width of the plates and the number of teeth of the nomophiles were studied independently.

Table 1. Characteristics of the seeds.
The quantitative variables were analyzed by different statistical tests according to their relevance: Analysis of Variance, Multiple Comparisons of Tukey, Significant Minimum Difference-DMS and Bonferroni, considering significant statistical differences of less than 5\%. In a complementary way, Pearson correlation tests were performed for the quantitative variables of the nomophiles. Additionally, the technique of Principal Component Analysis was applied, which allows to synthesize information and reduce the dimensionality of a data set (Zar, 1996; Pérez, 2004). The statistical analysis was carried out with the R programs, version 3.4.3 of free distribution and Spss, version 21.

Through the multivariate technique of cluster analysis, we sought to identify groups of quinoa varieties, according to their level of similarity in four variables: leaf length and width, length of petiole and number of teeth. Its graphics representation through the dendrogram facilitates the interpretation of Cluster analysis results, which, when used in a complementary manner with those obtained in the ACP, can complement results. The dendrogram was built with the software Minitab version 16, main menu statistics, with the multivariate instruction and conglomerate of variables, applying the Ward hierarchical grouping method and the Euclidean distance.

\section{RESULTS AND DISCUSSION}

Seed: The rapid appearance of the radicle after a few hours of imbibition (12 hours) agrees with the observations of Pitzschke (2018). FAO (2014) recommends that the germination percentage of stored seeds must exceed $85 \%$ so that these are profitable. Seeds of NE and PI did not exceed $70 \%$ germination (Table 1). The low germinative power of these two varieties could be related to a long period of storage of the seeds, and therefore a loss of latency, genetic erosion and low production (Alanoca et al. 2013; López \& Maldonado, 2013). While AM, BJ, BR, and TH their germination percentage exceeded the $85 \%$ recommended by FAO (2014).

\begin{tabular}{|c|c|c|c|}
\hline Variety & Average Germination Percentage & Average Diameter (mm) & Weight of One Thousand Seeds (g) \\
\hline BR & 98 & $2.14(\mathrm{~A})$ & 3.01 \\
\hline $\mathrm{NE}$ & 52 & $1.84(\mathrm{~B})$ & 2.04 \\
\hline $\mathrm{PI}$ & 62 & $2.18(\mathrm{~A})$ & 2.36 \\
\hline $\mathrm{AM}$ & 86 & $2.49(\mathrm{C})$ & 4.02 \\
\hline $\mathrm{BJ}$ & 96 & $2.25(\mathrm{~A}, \mathrm{C})$ & 2.88 \\
\hline $\mathrm{TH}$ & 90 & $2.36(\mathrm{~A}, \mathrm{C})$ & 2.8 \\
\hline Variance & & Test statistic & - \\
analysis & - & $\mathrm{F}=\mathbf{1 1 . 5 5 6 , \text { with a P value of }}$ & \\
& & $\mathbf{0 . 0 0 0}$ & \\
\hline
\end{tabular}

ANOVA: Bonferroni, DMS and Tukey. Stocks with a common letter -between parentheses- are not significantly different ( $\mathrm{p}>$ 0.05). 
The values of the analysis of variance and the multiple comparison tests of Bonferroni, DMS, and Tukey indicate that there are significant differences with respect to the diameter of the seed, where the variety NE presents the lowest average, $1.84 \mathrm{~mm}$ and differs from the other five varieties. The varieties AM $2.49 \mathrm{~mm}, \mathrm{TH} 2.36 \mathrm{~mm}$, and BJ $2.25 \mathrm{~mm}$ have the highest values and there are no significant differences between them, so they would form a group $\mathrm{C}$, under a level of significance less than or equal to $5 \%$ (Table1).

Vilche et al. (2003) proposed three ranges to classify Ch. quinoa seeds according to their diameter: large $2.2-2.6 \mathrm{~mm}$; medium $1.8-2.1 \mathrm{~mm}$ and small $1.0-1.7 \mathrm{~mm}$. In the same way, the seeds of $A M, B J$, and $T H$ are large while those of BR, $\mathrm{NE}$ and PI are medium (Table 1). Considering the weight of a thousand seeds and as reported by Delgado et al. (2009), could be taken as varieties of large grain AM and BR, since the weight of a thousand grains exceeds 3 grams. Likewise, the $\mathrm{BJ}$ and $\mathrm{TH}$ varieties have a medium grain since the weight of a thousand grains was between 2.5 and 3.0 grams. Finally, the NE and PI varieties, when having weights less than 2.5 grams, could be considered small grain varieties. The characterization of the seeds showed that AM possesses the grain with greater diameter and weight between the compared varieties, while NE and PI have the lowest values. From the commercial point of view, the size of the grain is of great importance (Mujica et al. 2004), AM, BJ and TH varieties are of greater interest for Boyacá producers, since according to their size and weight they can be considered as varieties of the special class (IBNORCA, 2002).

Seedlings the NE and PI varieties emerged on the fifth day, taking one day longer than the other varieties: Betancourth et al. (2007) report up to six and seven days for the emergence in the $\mathrm{BJ}$ and $\mathrm{TH}$ varieties, in tests done in the department of
Nariño at altitudes of 2.500 and $2700 \mathrm{~m}$. In general, the NE and PI varieties require a greater number of days until reaching the phenological stages evaluated, while the varieties AM, and BR are the earliest (Table 2). According to the analysis of variance, significant differences were found in the varieties in terms of the seedling height $(F=1339,8 ; p=0,000)$ and the length of the sheets of the cotyledons $(F=174,3 ; p=$ 0,000 ). The results of the multiple comparison tests of Bonferroni, DMS, and Tukey showed that NE and PI are grouped because they have a lower growth than the other varieties during all the days of measurement (Figure 1, Panel I). Likewise, AM presents slightly higher growth. With respect to the length of the cotyledons, AM also stands out for the higher average, while PI showed the smaller cotyledons (Table 2). Results that coincide with Boubaker et al. (1999), who report that large seeds produce seedlings with higher growth and the length of cotyledons. BJ and TH showed the highest average width and length of the primary leaves, while BR and PI presented the smallest leaves (Table 2). The Pearson correlation test showed a high relation $(0,9)$ between the width and the length of the leaves. All varieties showed pigmentation in the hypocotyl and cotyledons coinciding with that reported by Torres et al. (2000), for 18 varieties. The pigmentation increases on the seventh day, after sowing, according to what was reported by Paśko et al. (2009). Pigmentation of the hypocotyl allows to differentiate the varieties into two groups, $\mathrm{BJ}, \mathrm{BR}$, and $\mathrm{PI}$ with weak coloration and in $\mathrm{AM}, \mathrm{NE}$ and $\mathrm{TH}$ it is strong. In addition, the strong coloration of the cotyledons in $\mathrm{AM}$ the difference of the other varieties (Table 2).

Adult plants: The PI variety presents the highest values in the width and length of the sheet, the number of teeth in the margin and length of the petiole (Table 3), however, it does not exceed the maximum values described by Torres et al. (2000) for these same variables. The analysis of variance

Table 2. Qualitative and quantitative data obtained from the monitoring of the development of the seedlings until the appearance of the third pair of leaves.

\begin{tabular}{|l|c|c|c|c|c|c|}
\hline \multicolumn{1}{|c|}{ VARIETY } & BJ & TH & AM & PI & BR & NE \\
\hline Days to emergence substrate & 4 & 4 & 4 & 5 & 4 & 5 \\
\hline Days appearance primary leaves & 12 & 11 & 10 & 13 & 10 & 12 \\
\hline Days appearance 2 ${ }^{\text {nd }}$ pair leaves & 26 & 27 & 25 & 28 & 25 & 27 \\
\hline Days appearance 3rd pair leaves & 40 & 42 & 40 & 45 & 39 & 40 \\
\hline Hypocotyl pigmentation & weak & strong & strong & weak & weak & strong \\
\hline $\begin{array}{l}\text { Pigmentation } \\
\text { cotyledon }\end{array}$ & weak & weak & strong & weak & weak & weak \\
\hline Length of cotyledons (cm) & 1.80 & 2.43 & 2.63 & 1.43 & 1.83 & 2.17 \\
\hline Width Primary leaves $(\mathrm{cm})$ & 1.225 & 1.2125 & 0.95 & 0.725 & 0.775 & 1.087 \\
\hline Length of the Primary Sheets (cm) & 1.6375 & 1.6625 & 1.4125 & 1.0875 & 1.3875 & 1.4375 \\
\hline
\end{tabular}




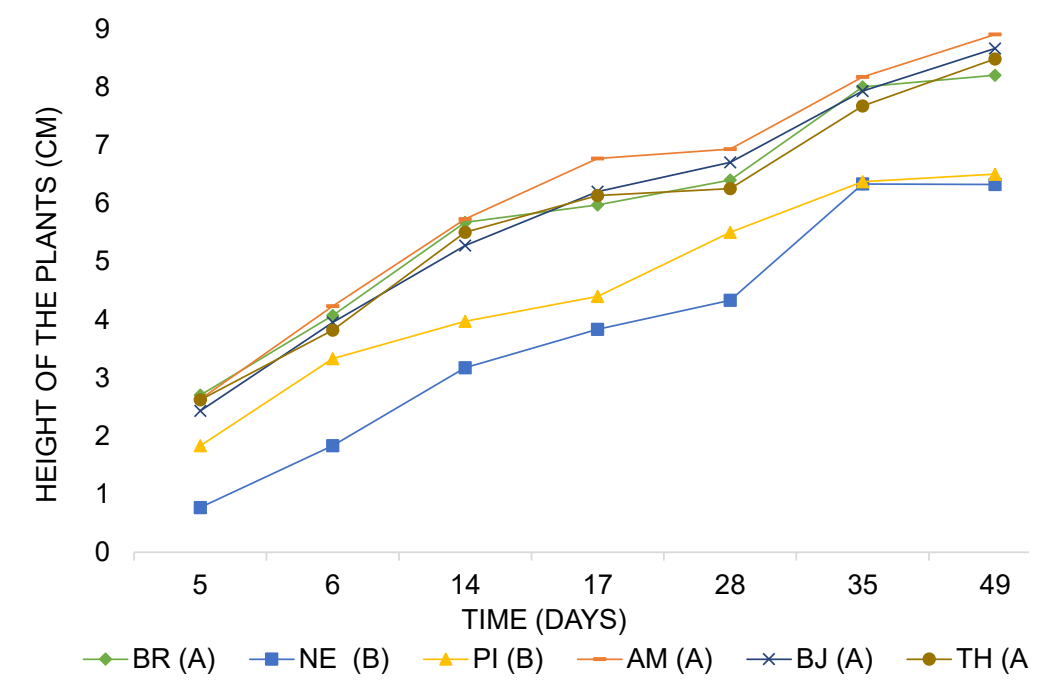

II.
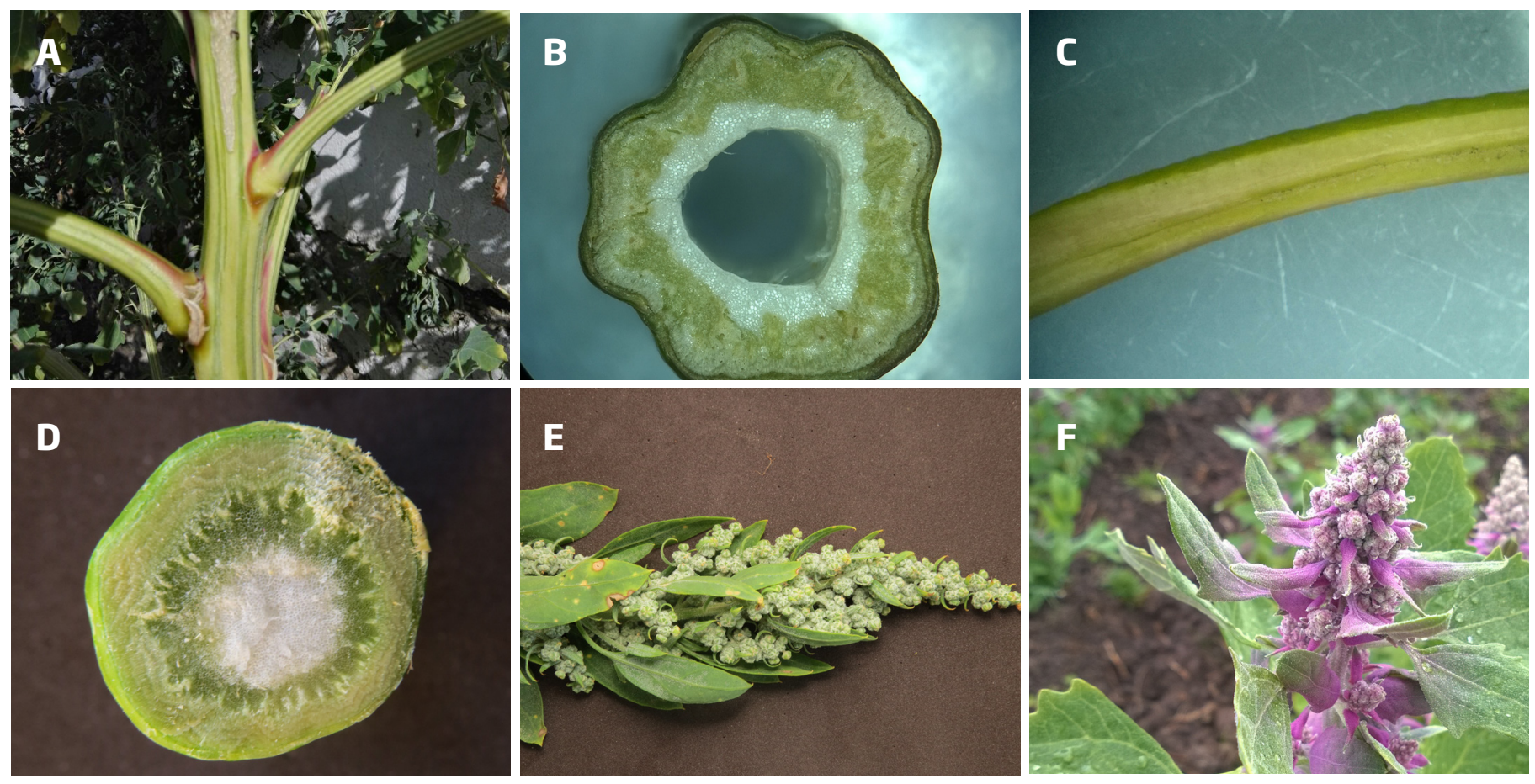

Figure 1. Characteristic of Ch. quinoa. Panel I. Average height $(\mathrm{cm})$ of the seedlings according to variety and days of measurement. ANOVA Test: Bonferroni, DMS and Tukey. Varieties with a common letter -between parentheses- are not significantly different ( $p>0.05$ ). Panel II. Morphological characteristics in Ch. quinoa varieties: A) Discolored stalk and axils with red or purple epidermis in PI; B) Cross section of stem with ribs in AM; C) Petioles channelized adaxially in AM; D) Stem without ribs in BJ; E) Inflorescence green-dark and green-glaucous BJ; F) Purple inflorescence TH.

showed significant statistical differences between some varieties, with respect to the width and average length of the sheet (Table 3). The tests of multiple comparisons showed that between the $\mathrm{BJ}$ and $\mathrm{TH}$ varieties there are no significant differences with respect to the mean width and length of the sheet, nor between the AM and PI varieties. There are significant differences in the average length of the petiole. The multiple comparison tests showed that the PI variety with a 
longer length is the only one that differs from the others (Table 3). There were statistically significant differences in the average number of teeth of the nomophiles. The Bonferroni, DMS and Tukey tests again concluded that the PI variety is the only one that differs from the others with a higher value in the average number of teeth of the nomophiles. According to the Pearson test there is a significantly high correlation $(0,847)$ between the width and length of the lamina, as well as a medium-high correlation $(0,672)$ between the length of the petiole and the number of teeth of the nomophiles, which coincides with the described by Torres et al. (2000), who found a positive-high correlation between these. The correlation between the length of the long-leaf petiole $(0,442)$; length of the lamina-number of teeth of the nomophiles $(0,463)$; width of the blade-length of the petiole $(0,475)$ and width of the blade-number of teeth of the nomophiles $(0,536)$ is medium and are significant at $5 \%$. Given that $C h$. quinoa has a very wide geographical distribution, both altitudinal and latitudinal, it is possible that leaf morphological structures vary depending on the environment and their genetic plasticity (González et al. 2014). According to Cabrol et al. (2014), intense UVB radiation is common in the Andes, due to the high altitude and the thin atmosphere. The decrease of the foliar surface can be related to a better adaptation to environments with high irradiation (González et al. 2014; Ivanova, 2014), as the environmental conditions present in the department of Boyacá, however, only physiological adaptations have been confirmed in quinoa. at increasing doses of UVB radiation (Reyes et al. 2018).

Figure 2, Panel I, shows that the variables, length of the petiole and number of teeth have the greater association with the PI variety. The long and wide variables of the lamina have a relative association in AM. With the first two components, $88,1 \%$ of the variability is explained. The eigenvectors allow obtaining the coefficients with which each original variable was weighted, to confirm the main components CP1 and

Table 3. Quantitative data of nomophiles.
$\mathrm{CP} 2$. The variable width of the sheet receives the highest positive weight $(0,532)$, all other variables receive positive weights on axis 1 (CP1). It stands out on axis 2 (CP2), the long variable petiole receives the highest positive weight $(0,560)$, and the length of the blade receives the highest negative weight $(-0,517)$. These variables are what most differentiates the varieties in this axis.

Aggregation of quinoa varieties according to quantitative variables (blade length and width, petiole length and number of teeth), Ward's hierarchical clustering method and Euclidean distance allow the identification of two groups with a similarity of 77, 36 (Figure 2, Panel II). The group (1) of red color consists mainly of the varieties $\mathrm{BJ}, \mathrm{TH}$, and $\mathrm{AM}$, the group (2) of blue color, formed only by the variable PI. Thus, in the dendrogram the confirmation of the clusters or conglomerates is reflected, as well as the distance among them, reflecting the greater distance of the PI variety, and greater closeness between the $\mathrm{BJ}, \mathrm{TH}$ and $\mathrm{AM}$ varieties, in terms of the variables studied.

Enlarged Description. Enlarged description of Chenopodium quinoa: Based on the reproductive and vegetative characteristics of the varieties studied (Table 4).

Plant polygamous-monoecious, herbaceous, annual, erect, 1,30-1,70 m high, with ascending branches. Fibrous root, axonomorphic, woody, root system allorrizia, primary root up to $25 \mathrm{~cm}$ and secondary roots up to $96 \mathrm{~cm}$ long. Cylindrical stem, with six to eight ribs, radial symmetry, 2,3-4,5 cm in diameter, discolored, with or without pigmented axils or ribs up to $5 \mathrm{~mm}$ high, porous and easily compressible marrow. Leaves deciduous, alternate, simple, membranous, deltoid to trullate, margin erose, of up to 42 teeth, apex obtuse to mucronulate, oblique base; actinodromous, basal and reticulated venation; opaque, pustulated surface-tiny blisters of a fraction of a millimeter-covered by small glands and petiole green or green-red, adaxially channelized or without longitu-

\begin{tabular}{|c|c|c|c|c|}
\cline { 2 - 5 } \multicolumn{1}{c|}{} & $\begin{array}{c}\text { Long Art Print } \\
(\mathbf{c m})\end{array}$ & $\begin{array}{c}\text { Width Art Print } \\
(\mathbf{c m})\end{array}$ & Long Petiole (cm) & $\begin{array}{c}\text { Number of No- } \\
\text { mophilic Teeth }\end{array}$ \\
\hline PI & $8.25(\mathrm{~B}, \mathrm{C})$ & $8.00(\mathrm{~B}, \mathrm{C})$ & $6.19(\mathrm{~B})$ & $37.33(\mathrm{~B})$ \\
\hline AM & $7.97(\mathrm{~B})$ & $7.56(\mathrm{~B})$ & $4.30(\mathrm{~A})$ & $17.57(\mathrm{~A})$ \\
\hline BJ & $6.20(\mathrm{~A})$ & $5.76(\mathrm{~A})$ & $4.39(\mathrm{~A})$ & $16.86(\mathrm{~A})$ \\
\hline TH & $6.09(\mathrm{~A})$ & $5.76(\mathrm{~A})$ & $3.96(\mathrm{~A})$ & $14.86(\mathrm{~A})$ \\
\hline Variance analysis & $\mathrm{F}=6.535 \mathrm{p}=0.002$ & $\begin{array}{c}\mathrm{F}=11.083 \\
\mathrm{p}=0.000\end{array}$ & $\mathrm{~F}=8.963 \mathrm{p}=0.000$ & $\mathrm{~F}=99.82 \mathrm{p}=0.000$ \\
\hline
\end{tabular}

ANOVA: Bonferroni, DMS Tukey. Stockings with a common letter are not significantly different $(p>0.05)$. 

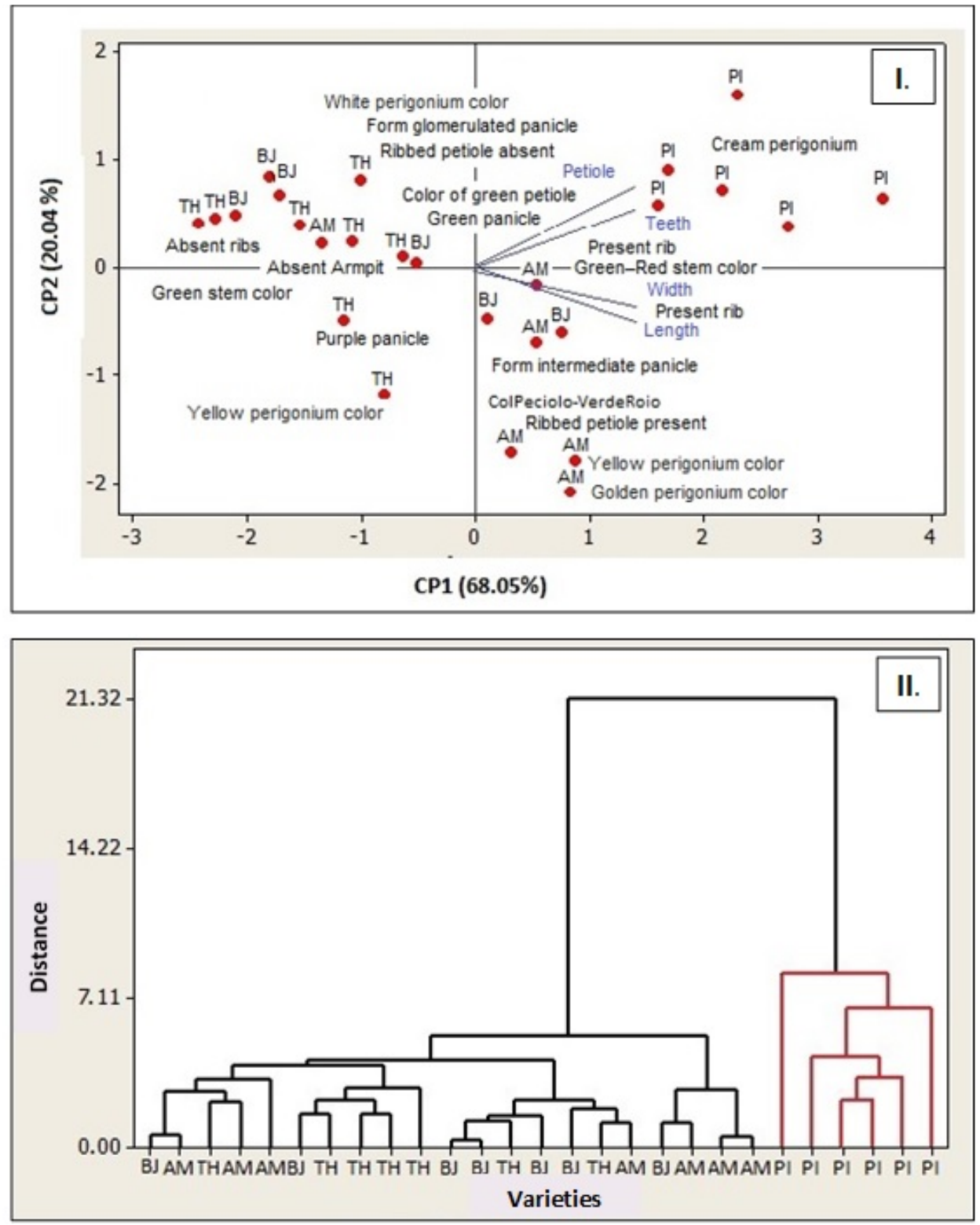

Figure 2. Qualitative characteristics and Euclidean distances in varieties of Ch. quinoa. Panel I Biplot graph, main components of the quantitative variables and their relationship with $C h$. quinoa varieties. Panel II. Dendrogram from Euclidean distance for four quinoa varieties, based on four quantitative variables. 
Table 4. Comparative table of morphological characteristics in the four varieties of Chenopodium quinoa studied.

\begin{tabular}{|c|c|c|c|c|}
\hline & $\mathrm{AM}$ & BJ & PI & TH \\
\hline Height of the plant (m) & $1.35-1.70$ & $1.30-1.60$ & $1.35-1.70$ & $1.35-1.70$ \\
\hline Long primary root $(\mathrm{cm})$ & 19 & 24 & 20 & 21 \\
\hline Long secondary root $(\mathrm{cm})$ & $37-96$ & $20-35$ & $21-37$ & $22-40$ \\
\hline Diameter of the stem $(\mathrm{cm})$ & $2.5-3.5$ & $2.3-4.5$ & $3.0-4.0$ & $3.0-4.0$ \\
\hline Stem coloring & $\begin{array}{l}\text { Green with red to } \\
\text { purple tones }\end{array}$ & $\begin{array}{l}\text { Green-light and } \\
\text { dark-green list }\end{array}$ & $\begin{array}{l}\text { Green-light and } \\
\text { dark-green list }\end{array}$ & $\begin{array}{l}\text { Green-light and } \\
\text { dark-green list }\end{array}$ \\
\hline Pigmented Axils & present & Absent & Present & Absent \\
\hline Presence of Ribs & present & Absent & present & Absent \\
\hline $\begin{array}{l}\text { Maximum number of teeth of the } \\
\text { nomophiles }\end{array}$ & 22 & 20 & 42 & 18 \\
\hline Petiole color & Green-red & Green & Green & Green \\
\hline Adaxially channelized petiole & Present & Absent & Absent & Absent \\
\hline Margin of bracts and bracts & $\begin{array}{l}\text { Whole or with one } \\
\text { to four teeth }\end{array}$ & $\begin{array}{l}\text { Whole or with one } \\
\text { to two teeth }\end{array}$ & $\begin{array}{l}\text { Whole or with one } \\
\text { to two teeth }\end{array}$ & $\begin{array}{l}\text { Whole or with one to } \\
\text { four teeth }\end{array}$ \\
\hline Panicle shape & Intermediate & Intermediate & Glomerulated & Glomerulated \\
\hline Panicle color & Green-white & Green-white & Green-white & Purple \\
\hline Color of the pericarp & Yellow-gold & White & White & White \\
\hline
\end{tabular}

dinal groove. Bracts and lanceolate bracts, entire margin or with one to four teeth and completely covered with glands. Inflorescence racemose-paniculated, glomeruled, intermediate or amarantiform. Actinomorphic flower, hypogynous, complete and incomplete, hermaphrodite or unisexual, perfect or imperfect, homochlamydeuos; dialycepetalous, calycine, green with white margins, covered by papillae translucent to purples; five stamens let's stand on curved filaments, antithesis; antigens biloculars, dithecas, versatile, connate, parallel and introrse. Apocarpous gynoecium, superior ovary, apical style, and bifurcated stigma. Fruit simple, dry, indehiscent, achene, monosperm, white or orange pericarp, in the mature state with remnants of perigonium. Albuminous seed, $1,8-2,5 \mathrm{~mm}$ in diameter, peripheral embryo, vitreous episperm.

\section{TAXONOMIC KEY}

1. Stems with ribs and epidermis of the red or purple axils Figure 1, Panel II, A-B). Margin of the nomophiles with 20-40 teeth (Table 4) .2

2. Reddish and adaxially canalized petiole

(Figure 1, Panel II, C) AM

2'. Petiole green and without the longitudinal groove.........PI

1'. Stems without ribs and with the epidermis of the axils of the samecolor asthestem(Figure 1,PanelII,D). nomophileswith less than 20 teeth. .3

3. Inflorescence green-dark and green-glaucous (Figure 1,

Panel II, E) ..... BJ

3'. Purple inflorescence (Figure 1, Panel II, F)..................TH

According to the altitude at which the crops were found, $2.538-2.810 \mathrm{~m}$, these are adapted to the ecological conditions of the inter-Andean valleys (Jellen, 2014; Graf et al. 2016; Zhang et al. 2017). 
Adult plants were found, constant morphological characters such as the presence of ribs, pigmented axils and number of teeth in the nomophiles, which allowed recognizing the cultivated varieties in the department of Boyacá, see the taxonomic key (Tables 3, 4).

The problem facing growers in Boyacá is the planting of a mixture of varieties, which produce different grain sizes and saponin concentrations, among other characteristics, which affects the quality and yield of the derived products and therefore their commercialization. These characterizations make it possible to document the varieties in written form, to broaden the ancestral knowledge of the farmers in Boyacá, which serve as an input to produce homogeneous crops and certified seeds of each variety, which would solve the problems.

Acknowledgments: The authors express their gratitude to the Vice-Rector for Research and Extension de la Universidad Pedagógica y Tecnológica de Colombia for the funding. To the Agricultural Engineer María Victoria Ballén of Laboratorio de Biotecnología Vegetal, de la Dirección de la Secretaría de Agricultura del Departamento de Boyacá, for supplying the seeds. To the growers of the municipalities of Siachoque, Tibasosa, and Tunja. Conflict of interests: The manuscript was prepared and reviewed with the participation of all authors, who declare that there is no conflict of interest.

\section{REFERENCES}

1. ALANOCA, C.; GUZMAN, D.; LUTINO, S.; IQUIZE, E. 2013. Evaluación de la germinación de accesiones del Banco de Germoplasma de quinua (Chenopodium quinoa Willd.) del estado plurinacional de Bolivia. Rev. Cient. Inv. INFO-INIAF (Bolivia). 1:23.

2. BAZILE, D.; BERTERO, D.; NIETO, C. (Editores). 2014. Estado del arte de la quinua en el mundo en 2013. FAO (Chile) y CIRAD (Francia). 724p.

3. BETANCOURTH, C.; BARCO, O.; ROSAS, I.D. 2007. Evaluación y transferencia de tecnología para tres genotipos promisorios de quinua dulce (Chenopodium quinoa Willd) en los municipios de Pasto y Guaitarilla del Departamento de Nariño. Rev. Cienc. Agr. (Colombia). 24(1):74-87.

4. BOUBAKER, M.; BEN, M.; GDIRI, H. 1999. Réponse du blé dur au stress hydrique et à la profondeur de semis pendant le stade jeune plante. Sécheresse (Francia). 10(1):35-38.

5. CABROL, N.A.; FEISTER, U.; HÄDER, D.P.; PIAZENA, H.; GRIN, E.A.; KLEIN, A. 2014. Record solar UV ir- radiance in the tropical Andes. Front. Environ. Sci. (United Kingdom). 2:19.

6. DELATORRE, J.; SÁNCHEZ, M.; DELFINO, I.; OLIVA, M. 2013. La quinua (Chenopodium quinoa Willd), un tesoro andino para el mundo. Idesia (Chile). 31(2):111-114.

7. DElgado, A.; PALACIOS, J.; BETANCOURT, C. 2009. Evaluación de 16 genotipos de quinua dulce (Chenopodium quinoa Willd.) en el municipio de Iles, Nariño (Colombia). Agron. Colomb. (Colombia). 27(2):159-167.

8. DEPARTAMENTO ADMINISTRATIVO DE PLANEACIÓN DE BOYACÁ. 2016. Anuario Estadístico. Available online in: http://www.dapboyaca.gov.co [access on 03/09/2018].

9. DUEÑAS, D.M. 2014. Competitive surveillance of quinoa: Potential for the Boyaca Department. Suma de Negocios (Colombia). 5(12):85-95.

10. FAO. 2014. Normas para bancos de germoplasma de recursos fitogenéticos para la alimentación y la agricultura. Roma. E-ISBN 978-92-5-308262-9. Available online in: http://www.fao.org/3/a-i3704s.pdf [access on 09/01/2018].

11. FONT, Q.P. 1979. Diccionario de Botánica. Editorial Labor (México). 1244p.

12. GONZÁLEZ, J.A.; BRUNO, M.; VALOY, M.; PRADO, F.E. 2011 Genotypic variation of gas exchange parameters and leaf stable carbon and nitrogen isotopes in ten quinoa cultivars grown under drought. J. Agron. Crop Sci. 197:81-93.

13. GONZÁLEZ, J.A.; KONISHI, Y.; BRUNO, M.; VALOY, M.; PRADO, F.E. 2012. Interrelationships among seed yield, total protein and amino acid composition of ten quinoa (Chenopodium quinoa) cultivars from two different agroecological regions. J. Sci. Food Agric. (England). 92:1222-1229.

14. GONZÁLEZ, J.A.; PONESSA, G.I.; BUEDO, S.E.; MERCADO, M.I.; PRADO, F.E. 2014. Asimilación fotosintética máxima en variedades de quinoa (Chenopodium quinoa) de diferentes orígenes geográficos y su relación con la morfología foliar. Lilloa (Argentina). 51(2):177-193.

15. GONZÁLEZ, J.A.; EISA, S.; HUSSIN, S.; PRADO, F.E. 2015. Quinoa: an Incan crop to face global chang- 
es in agriculture. In: Murphy, K.S.; Matanguihan, J. (eds). Quinoa: Improvement and sustainable production. Wiley-Blackwell, Hoboken (United States). p.1-18.

16. GRAF, B.L.; ROJO, L.E.; DELATORRE, J.; POULEV, A.; CALFIO, C.; RASKIN, I. 2016. Phytoecdysteroids and flavonoid glycosides among Chilean and commercial sources of Chenopodium quinoa: variation and correlation to physico-chemical characteristics. Sci. Food Agric. (England). 96(2):633-643.

17. IBNORCA. 2002. Norma Boliviana NB312004-ICS 67.060 Cereales, leguminosas y productos derivados. ICS 67.040 productos alimenticios en general. (Bolivia). 8p.

18. IVANOVA, L.A. 2014. Adaptive features of leaf structure in plants of different ecological groups. Russ. J. Ecol. (Rusia). 45(2):107-115.

19. JELLEN, E. 2014. Botánica, Filogenia y Evolución. In: Estado del arte de la quinua en el mundo en 2013. FAO-CIRAD (Chile-Francia). p.12-13.

20. LÓPEZ, M.P.; MALDONADO, S. 2013. Ricinosomes provide an early indicator of suspensor and endosperm cells destined to die during late seed development in quinoa (Chenopodium quinoa). Ann. Bot. (England). 112:1253-1262.

21. MASAAKI, S. 2014. Diversity in plant red pigments: anthocyanins and betacyanins. Plant Biotechnol. Rep. (Singapur). 8:37-48.

22. MINISTERIO DE AGRICULTURA Y DESARROLLO RURAL. 2005. Alianza cadena agroalimentaria de la Quinua. Estudio de preinversión alianza Quinua en Boyacá. Bogotá, Colombia. Available online in: http://www.misionrural.net/observatorio/alianzas/ productos/quinua/cucaita-samaca/PreInversionQuinuaBoyaca.pdf [access on 5/02/2018].

23. MINITAB STATISTICAL SOFTWARE. 2016. United States. Available online in: http://www.minitab. com/es-mx/products/minitab/pricing/ [access on 13/08/2018].

24. MONTOYA, L.A.; MARTÍNEZ, L.; PERALTA, J. 2005. Análisis de variables estratégicas para la conformación de una cadena productiva de quinua en Colombia. Innovar (Colombia). 15(25):103-119.
25. MORENO, N. 1984. Glosario botánico ilustrado. Instituto Nacional de Investigaciones sobre recursos bióticos. Compañía Editorial Continental (México). 300p.

26. MORILLO, A.; CASTRO, M.; MORILLO, Y. 2017. Caracterización de la diversidad genética de una colección de quinua (Chenopodium quinoa Willd). BSAA (Colombia). 15(2):49-56.

27. MUJICA, A.; JACOBSEN, S.; IZQUIERDO, J.; MARATHEE J. 2004. Quinua (Chenopodium quinoa Willd.) Puno-Perú. 17p.

28. PAŚKO, P.; BARTOŃ, H.; ZAGRODZKI, P.; GORINSTEIN, S.; FOŁTA, M.; ZACHWIEJA, Z. 2009. Anthocyanins, total polyphenols and antioxidant activity in amaranth and quinoa seeds and sprouts during their growth. Food Chem. (England). 115(3):994-998.

29. PÉREZ, C. 2004. Técnicas de análisis multivariante de datos. Aplicaciones con SPSS. Pearson Prectice Hall (Madrid). p. 456-672.

30. PITZSCHKE, A. 2018. Molecular dynamics in germinating, endophyte-colonized quinoa seeds. Plant Soil. (Australia). 422(1-2):135-154.

31. PRADO, F.E.; FERNÁNDEZ, J.L.; TSAROUCHI, M.; PSARAS, G.K.; GONZÁLEZ, J.A. 2014. Variation of seed mineral concentrations in seven quinoa cultivars grown in two agroecological sites. Cereal Chem. (Australia). 91(5):453-459.

32. REGUERA, M.; CONESA, C.M.; GIL-GÓMEZ, A.; HAROS, C.M.; PÉREZ-CASAS, M.Á.; BRIONES-LABARCA, V.; BOLAÑOS, L.; BONILLA, I.; ÁLVAREZ, R.; PINTO, K.; MUJICA, Á.; BASCUÑÁN-GODOY, L. 2018. The impact of different agroecological conditions on the nutritional composition of quinoa seeds. PeerJ (United States). 6:4442.

33. REYES, T.; SCARTAZZA, A.; CASTAGNA, A.; COSIO, E.; RANIERI, A.; GUGLIELMINETTI, L. 2018. Physiological effects of short acute UVB treatments in Chenopodium quinoa Willd. Sci. Rep. (United States). 8:371.

34. SAYAGO, J.; MARTÍNEZ, F.; GONZÁLEZ, D.; GONZÁLEZ, J.; ISLA, M. 2017. Análisis nutricional y funcional de plantas de quinoa cultivadas en el Noroeste Argentino. Dominguezia (Argentina). 33(1):85. 
35. TORRES, J.; VARGAS, H.; CORREDOR, G.; REYES, L.M. 2000. Morpho-agronornic characterization of nineteen cultivars of quinoa (Chenopodium quinoa Willd.) under Bogota's savanna conditions. Agron. Colomb. (Colombia). 17:61-68.

36. VEGA, A.; MIRANDA, M.; VERGARA, J.; URIBE, E.; PUENTE, L.; MARTÍNEZ, E.A. 2010. Nutrition facts and functional potential of quinoa (Chenopodium quinoa Willd.), an ancient Andean grain: a review. J. Sci. Food Agric. (United States). 90:2541-2547.

37. VELOZA, C.; ROMERO GUERRERO, G.; GÓMEZ PIEDRAS, J.J. 2016. Morphoagronomic response and protein quality of three accessions of quinoa (Chenopodium quinoa Willd.) in the northern sabana of Bogota. Rev. U.D.C.A Act. \& Div. Cient. (Colombia). 19(2):325-332.
38. VILCHE, C.; GELY, M.; SANTALLA, E. 2003. Physical properties of quinoa seeds. Biosyst. Eng. (United Kingdom). 86(1):59-65.

39. ZAR, J.H. 1996. Bio-Statistical Analysis. Prentice Hall, Upper Saddle River. (United States). 663p.

40. ZHANG, T.; GU, M.; LIU, Y.; LV, Y.; ZHOU, L.; LU, H.; ZHAO, H. 2017. Development of novel Indel markers and genetic diversity in Chenopodium quinoa through whole-genome re-sequencing. BMC genomics (United Kingdom). 18(1):685.

Received: December 5, 2017

Accepted: September 15, 2018

How to cite:

Infante R., H.; Albesiano, S.; Arrieta V., L.; Gómez V., N. 2018. Morphological characterization of varieties of Chenopodium quinoa cultivated in the department of Boyacá, Colombia. Rev. U.D.C.A Act. \& Div. Cient. 21(2):329-339. https://doi.org/10.31910/ rudca.v21.n2.2018.977 